\title{
(2) OPEN ACCESS \\ Global infectious disease risks associated with occupational exposure among non-healthcare workers: a systematic review of the literature
}

\author{
Sofie Acke (1),${ }^{1,2}$ Simon Couvreur, ${ }^{3}$ Wichor M Bramer, ${ }^{4}$ Marie-Noëlle Schmickler, ${ }^{2}$ \\ Antoon De Schryver, ${ }^{1}$ Juanita A Haagsma ${ }^{5}$
}

\begin{abstract}
- Additional supplemental material is published online only. To view, please visit the journal online (http://dx.doi. org/10.1136/oemed-2020107164).
\end{abstract}

${ }^{1}$ Family Medicine and Population Health (FAMPOP), Faculty of Medicine and Health Sciences, University of Antwerp Wilrijk, Belgium

${ }^{2}$ Research and Development, Mensura Occupational Health Services, Brussel, Belgium ${ }^{3}$ Department of Twin Research, King's College London, London, UK

${ }^{4}$ Medical Library, Erasmus MC, Rotterdam, The Netherlands ${ }^{5}$ Department of Public Health, Erasmus MC, Rotterdam, ZuidHolland, The Netherlands

\section{Correspondence to} Dr Juanita A Haagsma, Department of Public Health, Erasmus MC, 3000 CA Rotterdam, Netherlands: j.haagsma@erasmusmc.nl

Received 22 October 2020 Revised 7 February 2021 Accepted 12 February 2021

\section{Check for updates}

(C) Author(s) (or their employer(s)) 2021. Re-use permitted under CC BY. Published by BMJ.

To cite: Acke $S$, Couvreur $S$, Bramer WM, et al. Occup Environ Med Epub ahead of print: [please include Day Month Year]. doi:10.1136/ oemed-2020-107164

\section{ABSTRACT}

Objectives Employees in non-healthcare occupations may be in several ways exposed to infectious agents. Improved knowledge about the risks is needed to identify opportunities to prevent work-related infectious diseases. The objective of the current study was to provide an updated overview of the published evidence on the exposure to pathogens among non-healthcare workers. Because of the recent SARS-CoV-2 outbreaks, we also aimed to gain more evidence about exposure to several respiratory tract pathogens.

Methods Eligible studies were identified in MEDLINE, Embase and Cochrane between 2009 and 8 December 2020. The protocol was registered with International Prospective Register of Systematic Reviews (CRD42019107265). An additional quality assessment was applied according to the Equator network guidelines.

Results The systematic literature search yielded 4620 papers of which 270 met the selection and quality criteria. Infectious disease risks were described in 37 occupational groups; 18 of them were not mentioned before. Armed forces ( $n=36$ pathogens), livestock farm labourers $(n=31)$, livestock/dairy producers $(n=26)$, abattoir workers $(n=22)$; animal carers and forestry workers (both $n=16$ ) seemed to have the highest risk. In total, 111 pathogen exposures were found. Many of these occupational groups (81.1\%) were exposed to respiratory tract pathogens.

Conclusion Many of these respiratory tract pathogens were readily transmitted where employees congregate (workplace risk factors), while worker risk factors seemed to be of increasing importance. By analysing existing knowledge of these risk factors, identifying new risks and susceptible risk groups, this review aimed to raise awareness of the issue and provide reliable information to establish more effective preventive measures.

\section{INTRODUCTION}

Work-related diseases accounted for 2.4 million $(86.3 \%)$ of the total estimated deaths attributed to work in the updated report for the International Labour Organisation (ILO), published in 2017. Fatal occupational injuries accounted for the remaining $13.7 \%$. The estimated fatal work-related mortality by cause in the year 2015, mentioned in the same report, was as follows: circulatory diseases (31\%), work-related cancers $(26 \%)$, respiratory diseases (17\%) and occupational injuries (14\%). Communicable diseases counted for $9 \%$ and were more common in low-income countries.

\section{Key messages}

What is already known about this subject?

- Employees in different types of work may be in several ways exposed to biological agents: more or less accidentally, through animal contact or by contact with other humans.

\section{What are the new findings?}

- Many non-healthcare workers also have evidence of exposure to infectious pathogens; several new occupational groups and pathogens are described. Exposure to respiratory tract pathogens was mentioned in 30 out of 37 (81.1\%) non-healthcare occupations that met our inclusion criteria. Many of these respiratory tract pathogens are readily transmitted where employees congregate (workplace risk factors).

How might this impact on policy or clinical practice in the foreseeable future?

- A combined risk factors approach (disease and workplace and worker risk factors) may result in a comprehensive risk assessment strategy. More research is needed on the impact of workplace (eg, crowding, exposure to dust and welding fumes) and worker (eg, age and immunosuppression) risk factors to obtain a more systematic approach to prevent biological risks among non-healthcare employees.

They constituted slightly more than $30 \%$ of the work-related mortality in the African region vs less than $5 \%$ in high-income countries. The attributable fraction for infectious diseases was highest for women, both in high-income countries and other WHO regions (high-income region: men, 4.8\%, vs women, $32.5 \%$, and for the other regions: men, $3.1 \%$, vs women, $20.7 \%$ ). Morbidity from workrelated infectious diseases is expected to be much higher, although the true extent of incident cases is difficult to establish due to under-reporting. ${ }^{2}$ Educational interventions to increase this reporting of occupational diseases by physicians have been studied by a former systematic review. ${ }^{3}$

According to the WHO, work-related diseases have multiple causes, where factors in the work environment may play a role, together with other risk factors, in the development of such diseases. On the other hand, an occupational disease is any disease contracted primarily as a result of an 
exposure to risk factors arising from work activity. Occupational exposure is defined as exposure to potentially harmful chemical, physical or biological agents that occurs as a result of occupational factors. Only a small subset of biological agents-pathogens-may cause disease in humans. Infectious diseases can be transmitted via direct contact (including percutaneous), droplet, airborne (bioaerosol), vehicles (such as food, water and fomites) and vectors. Transmission of biological agents in the workplace may occur in two directions: workers can acquire infections in the workplace and then also may serve as vectors that spread the disease to others, such as clients and coworkers. Occupations involving interaction with subgroups of the general population, particularly infected persons, pose an increased risk of infection. Disease transmission patterns are also relevant to those whose work brings them in contact with animals, putting them at risk of zoonotic infections. ${ }^{24}$

Since the former key review of Haagsma et al, ${ }^{2}$ not only new occupations are noticed but also new pathogens like SARS-CoV-2. Also, some occupations (eg, welding) might increase susceptibility of workers to infection on exposure to an infectious agent, without increasing the exposure to the pathogen per se. ${ }^{56}$

In the current pandemic of the infectious disease COVID-19, the Belgian Centre for Occupational Disease Risks (Fedris) registered 7930 declarations for healthcare workers and 79 declarations for employees in other, essential sectors (police inspectors, warehouse worker-food salesmen and firefighters) up to 13 October 2020. Indeed, not only healthcare workers are affected by the pandemic SARS-CoV-2 virus. Although the majority of the earliest patient cases reported possible zoonotic or environmental exposure at the Huanan Seafood Wholesale Market in Wuhan, it is now clear that human-to human transmission has been occurring. ${ }^{8}$ Koh described a case report among staff in the tourism, retail and hospitality industry, transport and security workers, and construction workers in Singapore. ${ }^{9}$ Recently, the EFFAT (European Federation of Trade Unions, in the Food, Agriculture and Tourism) reported outbreaks in slaughterhouses and meat processing plants in several European countries (Germany, Ireland, The Netherlands, the UK, France, Poland, Italy, Norway, Spain, Belgium and Denmark). ${ }^{10}$ According to preliminary research findings, the following risk factors have been identified: lack of physical distancing and inspections, poor housing conditions, shared transport, insufficient ventilation, lack of (adequate) personal protective equipment and colder temperatures.

Although there is an increasing number of publications regarding emerging infections such as SARS-CoV-2, few are related to occupational health, especially among non-healthcare workers and over a wider geographical area. Moreover, such studies could contribute to evidence of new risk factors (eg, infectious bioaerosols) for acquiring infections in exposed groups. This will be crucial in the development of effective interventions to prevent transmission of potentially zoonotic or other pathogens. ${ }^{11}$

\section{Objectives of this study}

The objective of the current study was to provide an updated overview of the published evidence on the exposure to infectious pathogens in occupational groups other than healthcare workers. The second aim was to list significant work-related risk factors, including studies describing increased susceptibility to certain biological agents. By reason of the recent SARS-CoV-2 outbreaks, a third aim was to gain more evidence about exposure to respiratory tract pathogens among non-healthcare occupational groups.

\section{METHODS}

\section{Introduction}

This systematic review was performed according to the guidelines of the Preferred Reporting Items for Systematic Reviews and Meta-Analyses (http://www.prisma-statement.org). The objective was formulated using the PICOS criteria (PICOS: population: non-healthcare workers; intervention/exposure: exposures to environmental processes which involve many different microorganisms (composting, recycling and waste water recycling), through animal contact (agriculture and food processing) or through contact with humans; comparison: nonexposed workers or general population; outcome (primary): prevalence, incidence and/or occurrence rate of symptomatic infectious disease and/or seroconversion and/or immune-related and respiratory conditions; outcome (secondary): independent risk factors; and study: observational studies including cohort studies, case-control studies, cross-sectional studies, outbreak reports and case series (three or more cases).To avoid unnecessary duplication, the protocol was sent to the International Prospective Register of Systematic Reviews database and registered under the number CRD42019107265 (http://www.crd. york.ac.uk/PROSPERO/). Duplicate records were checked by EndNote V.X7.

\section{Definitions}

This study focused on biological agents such as bacteria, viruses, parasites or fungi, and was limited to work-related infectious disease, that is, infectious disease that is caused through workrelated exposure or exacerbated by work-related factors. ${ }^{12}$ The excluded healthcare occupations were the following: dental care workers, healthcare assistants, nurses and midwife (assistant), hospital dietary workers, laboratory workers, medical doctors (and students) and microbiologists. Childcare workers were also excluded because they have a care-related job too. Funeral service workers were excluded because they may have the same infectious disease risks as mortuary workers in hospitals, while veterinary doctors and assistants were excluded because some countries (eg, The Netherlands), have separate vets for companion animals (dogs and cats) and farm animals (cows and horses). Only in the latter case, they have the same risks as farmers. Biological agents that are non-infectious were excluded, such as moulds that can trigger allergies or produce toxins. Thus, lung diseases caused by sensitisation or toxic reactions through inhalation of non-infectious bioaerosols (eg, hypersensitivity pneumonitis and organic dust toxic syndrome) were excluded. Mite infestation by scabies was included in the case of an outbreak, as well as colonisation by antimicrobial resistant pathogens. Infections that were contracted outside working hours (eg, HIV and other sexually transmitted infections among truck drivers or armed forces) were excluded. The study focused both on workers in industrialised countries as well as on workers in low-income countries, and also included infectious disease risks through work-related travel, for instance, among armed forces posted overseas, or airline personnel. These workers might be exposed to increased risk of infection compared with the population of their country of origin, because of endemic infections in the country of destination. Of specific consideration is that many factors may combine to increase the risk of infection among workers during pathogen transmission. Categories of these risk factors for workrelated infections include disease factors (such as transmission 
mode), workplace factors (workplace characteristics, work practices and processes, and engineering and administrative issues), and worker factors (impaired immunity, inadequate prophylaxis, and socioeconomic and language factors). ${ }^{4}$

\section{Literature search}

First, SC performed a scoping review of published papers in PubMed between January 2009 and December 2017 based on the search strategy employed by Haagsma et al, ${ }^{2}$ which was extensively documented in the published report and its appendices. Second, for the updated systematic review of Haagsma et al until 8 December 2020, an extensive electronic search strategy in Medline, Ovid, Embase.com and Cochrane CENTRAL was developed in collaboration with JAH and librarian WMB who have broad experience with systematic reviews. Because this systematic search strategy yielded more than 30000 publications, the search terms were restricted by only screening the titles and major Medical Subject Headings (MeSH) terms, to include only articles where occupational diseases and infections were part of the major MeSH terms, or where these terms were mentioned in the title. The entire search profile is shown in the online supplemental appendix review 1.

\section{Inclusion criteria}

Publications included in the review had to meet the following inclusion criteria:

1. The study (or at least an abstract) was published in the period of 1 January 2009-8 December 2020.

2. Work-related (occupational) exposure.

3. The study concerned employees of a specific occupational group (age $\geq 16$ years); gender, language, ethnicity were not considered as inclusion/exclusion criteria.

4. The study concerned specified infectious pathogen(s).

5. Symptomatic infectious disease and/or seroconversion and/ or immune-related and/or respiratory conditions were used as outcome.

6. The exposure-associated risk for disease and/or seroconversion and/or immune-related and/or respiratory conditions was estimated by comparison to an appropriate reference population (for outbreak reports and case series, no reference group was needed).

\section{Data extraction}

Relevant papers were screened independently in two rounds by SA (systematic review, full period) and SC (scoping review, until December 2017). SA performed a double check of all titles screened by SC. Differences were resolved by discussion with experts (eg, ADS). JAH screened also the first $10 \%$ of the systematic review, which led to the exclusion of review papers. Six additional publications were added by experts. In the first round of the systematic review, the title and abstract were taken into consideration and compared with the inclusion criteria, based on the review by Haagsma et al. In case the titles and abstracts did not provide enough information, the articles were moved forward to the second round. In the second round, the title, abstract and the full text were assessed.

\section{Quality assessment}

An additional quality assessment was applied by SA in the third round according to the applicable reporting guidelines: Scottish Intercollegiate Guidelines Network (SIGN) ${ }^{13}$ for case-control and cohort studies, Strengthening the Reporting of Observational Studies in Epidemiology ${ }^{14}$ for cross-sectional studies, Outbreak
Reports and Intervention Studies of Nosocomial Infection ${ }^{15}$ for outbreak reports and Case Report Guidelines ${ }^{16}$ for case series.

\section{Synthesis of study results}

Results were first arranged in tabular form, listing all reported associations between pathogens and job titles or broader occupational groups. The International Standard Classification of Occupation (ISCO) of the ILO V.08 was used to classify job titles. ISCO classifies these job titles in four levels of aggregation in order to provide internationally comparable occupational data in a globalised market. We used level 3, which distinguishes 130 broader occupational groups. For some specific job titles, or where very specific associations were reported, level 4 subclassifications were used (table 1). Both levels are further defined as occupational groups. Subsequently, all occupational groups and their related pathogens were classified with their significant risk factors (online supplemental appendix review 2), and a random sample (systematic with random start, by SA in XLSTAT 2020) of pathogens with their corresponding disease, workplace and worker risk factors in table 2 .

\section{RESULTS}

After removal of duplicates, 4620 unique results that met our search terms and time period were obtained. In the first round (scanning the titles and abstracts), 1369 articles were retained, while 3251 articles were excluded because they did not meet our inclusion criteria. In the second round, 932 articles were excluded after reading the full text, based on the same criteria. In the third, qualitative synthesis round, another 167 articles were excluded, resulting in 270 eligible studies. Observational studies including cohort, cross-sectional studies, case-control, outbreak reports and case series (three or more cases) were the included study designs.

Figure 1 shows a flowchart of the literature screening process. The remaining 270 full-text articles were systematically reviewed on job title, occupational group (ISCO-08 codes) and associated pathogens. The results are summarised in table 1 . The literature review identified 37 occupational groups (classified by 38 ISCO-08 codes, at least at level 3) that were at risk of infectious disease. Studies describing infectious disease risks among 18 'new' occupational groups (not listed by the earlier review of Haagsma et al) met our inclusion criteria (marked in bold in table 1). The occupational groups which were most frequently reported on exposure to different pathogens were armed forces $(n=36$ pathogens), livestock farm labourers $(n=31$ pathogens), livestock/dairy producers ( $\mathrm{n}=26$ pathogens), abattoir workers ( $n=22$ pathogens), animal carers and forestry workers (both $\mathrm{n}=16$ pathogens). Altogether, occupational exposures to 111 different pathogens (on genus or, if available, species level) were found, some of which were overlapping between occupational groups. One out of three pathogens $(n=43$, on genus or species level, marked in bold in table 1) were not yet described by studies in the earlier review of Haagsma et al (eg, avian metapneumovirus, chikungunya virus, Crimean-Congo haemorrhagic fever virus, dengue virus, equine influenza virus, Marburg virus, Orientia tsutsugamushi, SARS-CoV-2 virus and Streptococcus pneumoniae). Our recent update from 18 April to 8 December 2020 yielded another 752 publications, whereof 426 were COVID-19 related. After the third, qualitative synthesis round, five COVID-19 publications (four outbreak reports and one cross-sectional study) and eight non-COVID-19 publications met our inclusion criteria. 
Table 1 Pathogens by specific job title or broader occupational groups

\begin{tabular}{|c|c|c|}
\hline Occupational group & ISCO code & Pathogen \\
\hline $\begin{array}{l}\text { Abattoir workers and related } \\
\text { food preparers }\end{array}$ & 7511 & $\begin{array}{l}\text { (Methicillin-resistant) Staphylococcus aureus, (swine (H3N2/H1N2) influenza virus, (avian) influenza virus (H9/H9N2), Avian } \\
\text { metapneumovirus, Bacillus anthracis, Brucella abortus spp, Campylobacter spp, Chlamydia psittaci, Coxiella burnetii, Escherichia coli, } \\
\text { Francisella tulariensis (=), hepatitis B virus, hepatitis E virus, Leptospira borgpetersenii/hardjo/interrogans/pomona, Rift Valley fever } \\
\text { virus, SARS-CoV-2 virus, S. aureus (=), Streptococcus pyogenes, Toxocara canis, Toxoplasma gondii (=) }\end{array}$ \\
\hline Airline personnel & 5111 & Hepatitis E virus, measles morbilivirus \\
\hline Animal carers & 5164 & $\begin{array}{l}\text { Bartonella hensalae, Borrelia burgdorferi, B. canis, Capillaria hepatica, C. psittaci, C. burnetii, hantavirus }(=) \text {, (canine H3N8 }(=) \text { ) influenza } \\
\text { virus, Leptospira spp, lymphocytic choriomeningitis virus, mouse retroviruses (XMRV }(=) / \text { MLV }(=)) \text {, simian foamy virus, simian } \\
\text { parvovirus, simian type D retrovirus, T. canis, T. gondii }(\approx)\end{array}$ \\
\hline Archaeologists & 211 & Coccidioides immitis \\
\hline Armed forces & 0000 & $\begin{array}{l}\text { (Methicillin-susceptible) S. aureus, adenovirus (7/11A/B), astrovirus, chikungunya virus, C. pneumoniae, coxsackie virus (A6), } \\
\text { C. burnetii, dengue virus, ECHO virus, hepatitis A/B/C ( } \approx \text { /E virus, influenza A(H1N1/H3N2/H1N1pdm09)/B virus, Legionella spp, } \\
\text { Leishmania spp, Leptospira spp, measles morbilivirus, Microsporum canis, Mycobacterium tuberculosis, mumps rubulavirus, } \\
\text { norovirus, Orientia tsutsugamushi, Plasmodium falciparum/ovale/vivax, respiratory syncytial virus, Ross River virus, non- } \\
\text { typhoidal Salmonella enteretica, sapovirus, Sarcoptes scabiei, SARS-CoV-2 virus, S. pneumoniae, S. pyogenes, Trypanosomi } \\
\text { cruzii (=), Yersinia enterocolica }\end{array}$ \\
\hline Bar workers & 513 & HIV (=) \\
\hline Barbers & 5141 & Hepatitis B virus (=) \\
\hline Building workers & 711 & C. immitis, Histoplasma capsulatum \\
\hline Cash collectors & 523 & M. tuberculosis \\
\hline Civil engineering labourers & 9312 & Legionella pneumophila \\
\hline Cleaners & 515 & Hepatitis A virus, hepatitis B virus, M. tuberculosis \\
\hline Divers & 7541 & Campylobacter jejuni, enteroviruses, Pseudomonas aeruginosa \\
\hline Farm workers, crops & 6111 & $\begin{array}{l}\text { B. burgdorferi, Clostridium tetani, C. immitis, C. burnetii, E. coli, F. tularensis, Leishmania spp, L. borgpetersenii/spp, Strongyloides } \\
\text { stercoralis, tick-borne encephalitis virus (=), Toscana virus (=), T. canis, usutu virus (=), West Nile virus (=) }\end{array}$ \\
\hline Firefighters & 5411 & Cryptosporidium parvum \\
\hline Fishmongers & 7511 & Anasakis simplex, hepatitis E virus \\
\hline Forestry workers & 6210 & $\begin{array}{l}\text { Anaplasma phagocytophilum, B. henselae, B. burgdorferi/miyamotoi, C. burnetii, Francisella tularensis, hantavirus, hepatitis E virus, } \\
\text { Leptospira spp (=), Rickettsia conorii, R. helvetica, tick-borne encephalitis virus ( } \approx) \text {, Toscana virus (=), T. gondii, usutu virus (=), West } \\
\text { Nile virus (=) }\end{array}$ \\
\hline Gardeners & 6113 & F. tularensis \\
\hline Hotel workers & 9112 & L. pneumophila \\
\hline Livestock and dairy producers & 6121 & 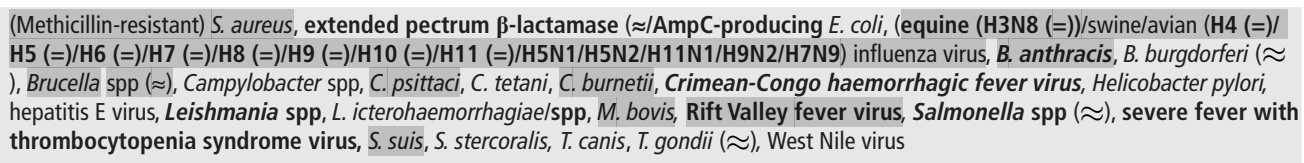 \\
\hline Livestock farm labourers & 9212 & $\begin{array}{l}\text { (Methicillin-resistant) S. aureus, (multidrug-resistant) S. aureus, (methicillin-resistant) coagulase-negative staphylococci, extended } \\
\text { spectrum } \beta \text {-lactamase/AmpC-producing E. coli, STEC 0157/non-(STEC) 0157, (avian (H4 (=)/H5 (=)/H6 (=)/H7 (=)/H8 (=)/H9 (=)/ } \\
\text { H10 (=)/H9N2/H5N2/H7N3/H11N1/H5N1/ } \\
\text { H7N9)/swine(H2N3 (=)/H3N2v/H1N1/H3N2/(H1N1)pdm09)/H1N2) influenza virus, Aspergillus flavus, A. fumigatus, B. burgdorferi, } \\
\text { Brucella spp, Campylobacter spp, Candida albicans, C. psittaci, Clostridium spp*, Clostridium tetani, C. burnetii, C. parvum, H. pylori, } \\
\text { hepatitis E virus, L. icterohaemorrhagiae, Moraxella spp* }{ }^{*} \text {, M. bovis, Prevotella spp* }{ }^{*} \text { R. conorii, R. felis, Rift Valley fever virus, non- } \\
\text { typhoidal S. enteretica, S. stercoralis, T. canis, T. gondii, West Nile virus }\end{array}$ \\
\hline Manicurists & 5142 & Hepatitis B virus (=), hepatitis C virus (=), HIV (=) \\
\hline $\begin{array}{l}\text { Mining and mineral } \\
\text { processing plant operators }\end{array}$ & 811 & $\begin{array}{l}\text { (Panton-Valentine leucocidin-producing methicillin-susceptible) S. aureus, Leptospira spp, Marburg virus, measles morbillivirus, } \\
\text { M. tuberculosis, Sporothrix schenckii }\end{array}$ \\
\hline Office clerks & 4110 & Mumps rubulavirus \\
\hline $\begin{array}{l}\text { Plant and machine operators } \\
\text { and assemblers (metal and } \\
\text { textile/leather) }\end{array}$ & $\begin{array}{l}812, \\
815\end{array}$ & $\begin{array}{l}\text { B. anthracis, C. burnetii, H. capsulatum, L. pneumophila, measles morbillivirus, mumps rubulavirus, M. chelonae, N. meningitidis C, S. } \\
\text { enteritidis, S. pyogenes, norovirus }\end{array}$ \\
\hline Police officers & 5412 & HIV (=), mumps rubulavirus, varicella zoster virus \\
\hline Prison guards & 5413 & M. tuberculosis \\
\hline $\begin{array}{l}\text { Professional drivers (bus } \\
\text { or taxi) }\end{array}$ & 8322 & Legionella spp, M. tuberculosis \\
\hline $\begin{array}{l}\text { Sex workers (female, male, } \\
\text { cis or transgender, internet } \\
\text { escort) }\end{array}$ & 5168 & $\begin{array}{l}\text { C. trachomatis, hepatitis B virus }(\approx) \text {, hepatitis } C \text { virus }(\approx) \text {, herpes simplex virus-2, HIV }(\approx) \text {, human papilloma virus (type } 6 / 16 / 18 / 31 / 33 \\
\text { /35/39/45/51/52/53,56/58/59/66/67/68), human T-lymphotrophic virus, Neisseria gonorrhoeae, Treponema pallidum }(\approx) \text {, Trichomonas } \\
\text { vaginalis }\end{array}$ \\
\hline Ship's stewards & 5111 & SARS-CoV- 2 virus \\
\hline Shop salespersons & 522 & SARS-CoV- 2 virus \\
\hline Social workers & 3412 & M. tuberculosis, Shigella sonnei \\
\hline Teachers, primary & 2341 & Cytomegalovirus, N. meningitidis \\
\hline Technicians & 313 & Mumps rubulavirus \\
\hline Television crew & 265 & C. immitis \\
\hline Waste collectors & 9611 & $\begin{array}{l}\text { Blastocystis hominis (=), Brucella spp, C. burnetii, Cryptosporidium spp (=), Entameuba histolytica (=), Giardia intestinalis (=), H. } \\
\text { pylori, hepatitis A virus, hepatitis B virus, hepatitis C virus ( } \approx) \text {, hepatitis E virus (=), Leptospira spp (=), T. gondii }\end{array}$ \\
\hline
\end{tabular}


Table 1 continued

\begin{tabular}{lll}
\hline Occupational group & ISCO code & Pathogen \\
\hline Wastewater workers & 3132 & $\begin{array}{l}\text { (Antibiotic-resistant) coagulase-negative staphylococci, (methicillin-resistant) S. aureus (=), methicillin-susceptible S. aureus } \\
(=), \text { vancomycin-resistant enterococci (=), vancomycin-susceptible enterococci, H. pylori }(=), \text { hepatitis A virus }(\approx), \text { hepatitis E } \\
\text { virus }(\approx), \text { H. capsulatum }\end{array}$ \\
Welders & 7212 & S. pneumoniae
\end{tabular}

Marked in bold are occupational groups or pathogens that were not yet described by studies in the former review of Haagsma et al. ${ }^{2}$ Pathogens with a possible portal of entry by inhalation (via the respiratory tract) are highlighted.

$=$, no increased risk when compared with a control group from the general population; $\approx$, some studies revealed no increased risk while other studies showed an increased risk.

*Nasopharyngeal microbiota content.

ISCO, International Standard Classification of Occupation; MRV, murine leukemia viruses; STEC, Shiga-toxin producing Escherichia. coli ; XMRV, xenotropic murine leukemia virus-related virus.

The mapping of studies per world region was as follows: Europe And Central Asia $(n=75)$, East Asia and Pacific $(n=67)$, North America $(n=38)$, sub-Saharan Africa $(n=33)$, Latin America and Caribbean $(n=28)$, Middle East and North Africa $(n=18)$ and South Asia $(n=11)$. Thus, most studies were administered in Europe and Central Asia (27.8\%), followed by East Asia and Pacific (24.8\%), North America (14.1\%) and sub-Saharan Africa (12.2\%) (https://ourworldindata.org/ world-region-map-definitions).

Online supplemental appendix review 2 includes a list of all reported associations between pathogens, job titles or broader occupational groups, and statistically significant risk factors separately for each article included in the review.

Exposure to respiratory tract pathogens (through human, animal or environmental pathways) was mentioned in 30 out of 37 (81.1\%) of included occupational groups: abattoir workers and related food preparers, airline personnel, animal carers, archaeologists, armed forces, building workers, cash collectors, civil engineering labourers, cleaners, farm workers (crops), forestry workers, gardeners, hotel workers, livestock and dairy producers, livestock farm labourers, mining and mineral processing plant operators, office clerks, plant and machine operators and assemblers, police officers, prison guards, professional drivers (bus or taxi), ship's stewards, shop salespersons, social workers, teachers, technicians, television crew, waste collectors, wastewater workers and welders.
Table 2 summarises combined, significant risk factors for pathogens with a global occurrence (avian influenza virus and Coxiella burnetii); work-related and travel-related infection risk (hepatitis E virus); or a single known risk factor (S. pneumoniae). Risk factors were subdivided in disease, workplace and worker risk factors. The full list of significant risk factors per pathogen is available in the online supplemental appendix review 2. For example, for $S$. pneumoniae infection, a single workplace risk factor (exposure to welding fumes and silica dust) was described by a recent study of Torén et al, ${ }^{5}$ while risk of hepatitis E virus infection through work-related travel, was mentioned for missions abroad among military forces (workplace factor). For hepatitis E virus, avian influenza virus and C. burnetii, additional disease and worker risk factors were described in several studies.

\section{DISCUSSION}

Work-related infectious diseases among non-healthcare workers include a wide variety of pathogens and occupational groups. Almost half of the listed occupational groups and one out of three listed pathogens were not yet described by studies in the earlier review of Haagsma et al. ${ }^{2}$ This is in accordance with the 2015 European Working Conditions Survey, in which an increasing proportion of European workers (13\%, which is 1.5 times as many as 10 years earlier) were indicated to be exposed to infectious agents at work. ${ }^{17}$ Although most of the reported

Table 2 Significant risk factors by described pathogens (the full list of references per pathogen is available in the online supplemental appendix review 2)

\begin{tabular}{|c|c|c|c|}
\hline Pathogen & Disease factor & Workplace factor & Worker factor \\
\hline Avian influenza virus & $\begin{array}{l}\text { Moderate poultry exposure (301-900 poultry-years) } \\
\text { Professional classification as a poultry seller }{ }^{22} \geq 10 \text { years of } \\
\text { occupational exposure }^{23}\end{array}$ & $\begin{array}{l}\text { Another stall nearby, number of cages (more } \\
\text { than five) }{ }^{24} \text { Workplaces near locations where } \\
\text { H5N2 outbreaks in poultry were reported } \\
\text { Wholesale/retail live poultry markets }^{26}\end{array}$ & $\begin{array}{l}\text { Female gender }{ }^{22} 23 \\
\text { Male gender }\end{array}$ \\
\hline Coxiella burnetii & $\begin{array}{l}\text { Contact with small ruminants (sheep and goats) }{ }^{29} \text { Cattle } \\
\text { contact at own or other farm }{ }^{30} \text { Keeping sheep or goats, } \\
\text { exposure to arthropod bites }{ }^{31} \geq 3 \text { daily goat-related tasks } \\
\text { (milking, feeding, supply and removal, general animal } \\
\text { healthcare and birth assistance), other goat breeds next } \\
\text { to white dairy goat }{ }^{32} \text { Milking cattle, general healthcare of } \\
\text { cattle, birth assistance, contact with raw milk, contact with } \\
\text { cattle manure, contact with dead-born animals }{ }^{33}\end{array}$ & $\begin{array}{l}\text { Presence of cat(s) in goat stable, distance } \\
\text { residence to nearest stable } \leq 10 \mathrm{~m} \text {, distance } \\
\text { to nearest positive farm } 0-<4 \mathrm{~km}^{28} \text { Passed } \\
\text { through the stores }{ }^{34}\end{array}$ & $\begin{array}{l}\text { Full working week, worked in cattle sector } \\
\text { in the past }{ }^{30} \mathrm{Age}>50 \text { years), rural area } \\
\text { of residence, having little or no formal } \\
\text { education }{ }^{31} \text { Lived as child on a ruminant farm, } \\
\text { no farm boots for staff }{ }^{32} \text { Male gender }{ }^{34} \text { No } \\
\text { respiratory protection mask }{ }^{35} \text { Living in rural } \\
\text { areas }^{36}\end{array}$ \\
\hline Hepatitis E virus & $\begin{array}{l}\text { Abattoir work, sewage work }{ }^{37} \text { Occupational contact } \\
\text { with animals (forestry/pig farm workers) }{ }^{38} \text { Slaughterers } \\
\text { Exposure to soil, contact with swine }{ }^{40} \text { Having professions } \\
\text { with exposure to pigs for more than } 16.5 \text { years }{ }^{41}\end{array}$ & $\begin{array}{l}\text { Unorganised swine farming }{ }^{37} \text { Woodcutting } \\
\text { Raw seafood processing }{ }^{43} \text { Feeding of pigs } \\
{ }^{44} \\
\text { Previous mission abroad (military forces) }\end{array}$ & $\begin{array}{l}\text { Consumption of pork-liver sausages } \\
\text { Residence area }{ }^{40} \text { Age } \geq 50 \text { years, age group } \\
25-34 \text { years, ascending age, ages } 40-49 \text {, } \\
50-59, \geq 60 \text { and over } 40 \text { years }{ }^{38} 4446-48 \\
\geq 7 \text { working years }{ }^{43} \text { Living in an area with } \\
\text { frequent flooding, consuming intern pig } \\
{\text { organs more than twice per week }{ }^{49} \text { Ever been }}_{\text {in Africa }}{ }^{50}\end{array}$ \\
\hline $\begin{array}{l}\text { Streptococcus } \\
\text { pneumoniae }\end{array}$ & & $\begin{array}{l}\text { Occupational exposure to welding fumes, } \\
\text { silica dust }^{5}\end{array}$ & \\
\hline
\end{tabular}




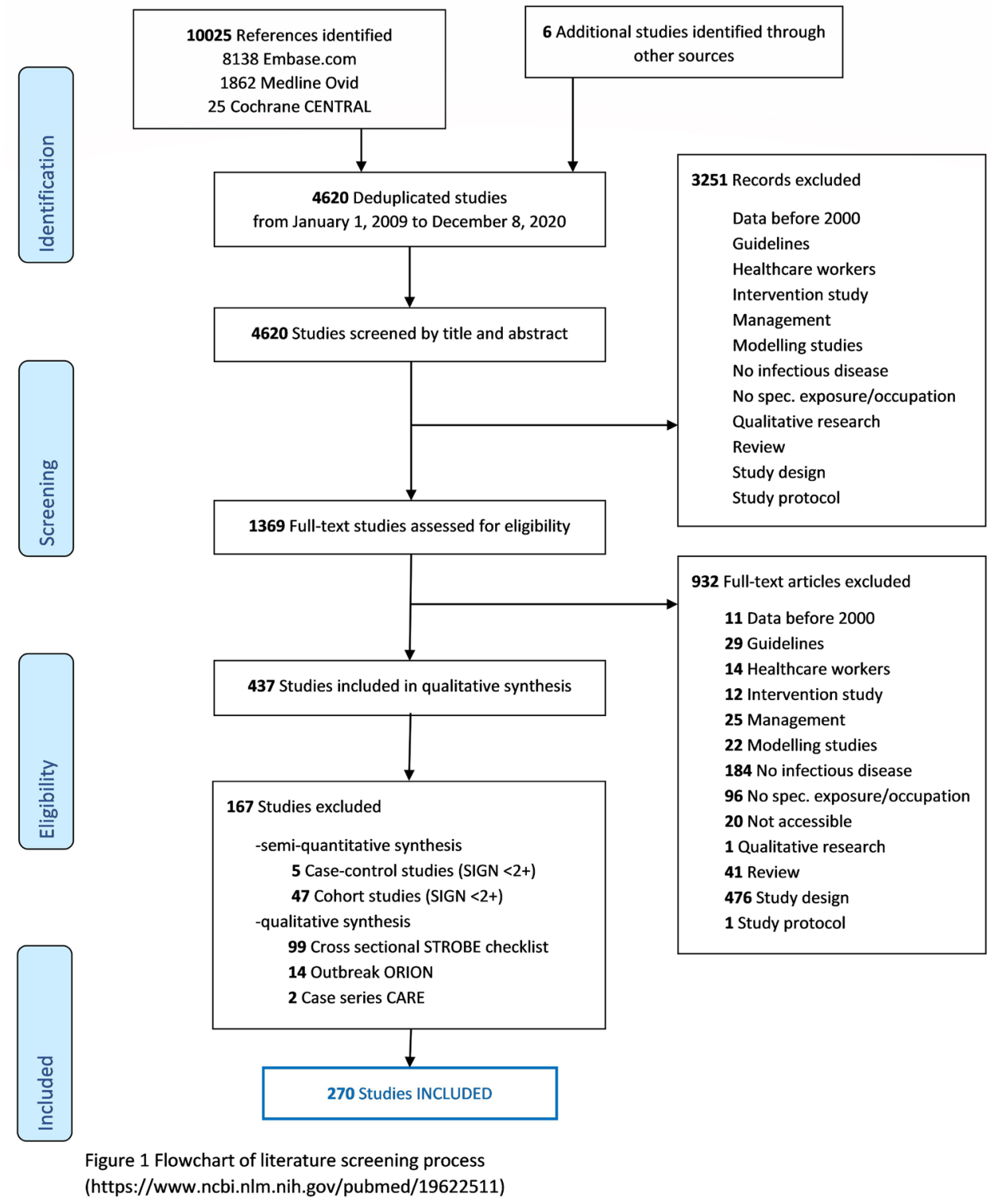

Figure 1 Flowchart of the literature screening process (https://www.ncbi.nlm.nih.gov/pubmed/19622511). CARE, Case Report Guidelines; ORION, Outbreak Reports and Intervention Studies of Nosocomial Infection; PRISMA, Preferred Reporting Items for Systematic Reviews and Meta-Analyses; SIGN, Scottish Intercollegiate Guidelines Network; STROBE, Strengthening the Reporting of Observational Studies in Epidemiology.

studies in the current review were of European and Central Asian origin (27.8\%), some of the infectious disease risks were limited to certain geographical regions (eg, Coccidioides immitis in North and Latin America and Rift Valley fever virus in subSaharan Africa). Other infectious disease exposures are reported globally (eg, Mycobacterium tuberculosis, Histoplasma capsulatum and S. pneumoniae). However, worker susceptibility may vary per region. These worker risk factors (age, gender, inadequate prophylaxis, and socioeconomic and language factors) seem to be of increasing importance, as seen in the increased number of papers reporting these worker risk factors over the last 10 years. Also, many immunosuppressant drugs (biologicals, glucocorticoids, antimetabolite drugs and inhibitors of cytokine production and function) and diseases (eg, HIV, stem cell or organ transplantation) result in impaired immunity and thus increase susceptibility to infectious disease risks, without increasing the exposure to the pathogen per se. More research in this domain is needed because it is estimated that a high number of employees work under this condition. ${ }^{18}$ Furthermore, migrant workers may also have an increased risk of infectious diseases in high-income countries due to language barriers, different prophylactic vaccination strategies and employment by several contractors. This results in a difficult implementation of outbreak control measures as illustrated in the recent $S$. pneumoniae outbreak on a shipyard in France. ${ }^{19}$ A combined risk factors approach may result in an extended risk assessment strategy based on the former exposure matrix of Haagsma et al, ${ }^{2}$ by combining human, animal and environmental transmission pathways (disease risk factors) with their corresponding workplace risk factors (eg, contact with dust, welding fumes and crowded work environment) and worker risk factors (eg, poor nutritional status, immunosuppression, pregnancy, smoking, viral 
coinfections and comorbidity). ${ }^{4} 1920$ Exposure to respiratory tract pathogens was mentioned in 30 out of $37(81.1 \%)$ of included non-healthcare occupational groups, indicating that biological hazards such as M. tuberculosis (among armed forces, cash collectors, cleaners, miners, prison guards, professional drivers and social workers), measles (armed forces, operators and miners) and SARS-CoV-2 virus (armed forces, meat processing workers, retail workers and ship's stewards) are not limited to healthcare workers and thus must be included in the risk analysis. Many of these respiratory tract infections are readily transmitted where employees congregate, for example, in transportation vehicles, correctional facilities, military barracks, slaughterhouses and meat-packing plants, and shipyards (workplace risk factors). Of special interest is the global occurrence of antimicrobial-resistant pathogens among abattoir workers, livestock dairy producers and farm workers, while the risk among wastewater workers seemed to be low. Most of these exposures lead to colonisation, which can lead to an infection in the case of a health event or weakened immune system conditions. One major limitation of this study is that the literature review was restricted to papers published in the period 2009-8 December 2020, while a strength might be that the findings since the year 1999 by the former review by Haagsma et al were also included. However, established and important occupationally induced infections that were recognised prior to 1999 may not have been included in more recent publications and consequently in this review because they are no longer new findings. On the other hand, studies are still being conducted on recent hazards such as the SARS-CoV-2 virus. Furthermore, the search profile may not have yielded all articles on occupational exposure to infectious disease, due to the focus on non-healthcare workers and the terms used in the search strategy. Including the search term 'respiratory conditions' as outcome, yielded much more records and subsequently infectious diseases risks among military forces. In light of this limitation, we recommend further exhaustive searches using the exposure matrix proposed in Haagsma et al and other sources such as the Latin American and Caribbean Health Sciences Literature Database (Lilacs http://lilacs.bvsalud. org/). Another limitation is that we did not include mortality or hospitalisation studies because they did not meet our inclusion criteria. In the first place, we wanted to provide an overview of risk factors for disease. Risk factors for mortality (and also for hospitalisation) could possibly be checked in a subsequent review, also because there are probably other/supplementary risk factors for these outcomes. Because there was a large heterogeneity in occupational groups $(n=37)$, pathogens $(n=111)$, measures of effect and study designs (eg, outbreak reports, $\mathrm{n}=84$ ) in the studies that met our inclusion criteria, it was not appropriate to conduct a meta-analysis. Another limitation of our study was that the occupational aspects in many published papers (in non-occupational journals) are often downplayed by the authors, resulting in information and selection bias. In contrast to the earlier review by Haagsma et al, ${ }^{2}$ also studies reporting non-significant differences or lower risks in the same occupational risk were included, in order to try to minimise potential publication (selection) bias. In addition, the condition 'symptomatic infectious disease and/or seroconversion' was extended with 'immune-related and/or respiratory conditions' to enhance inclusion of immune-related diseases and respiratory tract pathogens. Still, due to reporting and selection biases, the included occupational groups are almost certainly not representative of the whole set of non-healthcare occupations. By adding the qualitative screening step, more information could be gained about the strength of causality, the precision of the estimated association between exposure and outcome, and the independence of risk factors. For example, cohort studies were, according to the SIGN criteria, ${ }^{13}$ only included if they were prospective; only studies that reported values with confidence limits were included. Some trends which were observed during the screening process might be of interest. First, 716 studies $(51.1 \%$ of the assessed full texts) were excluded because of inadequate study design, specifically lack of comparison of incidence or prevalence to an adequate reference population. Certainly, some of the studies in this group were never designed to answer the question of occupational risk. For example, many studies of HIV in sex workers addressed the effectiveness of interventions or differential prevalence and incidence in subgroups of sex workers (eg, outdoor sex work, cisgender vs transgender, internet escorts). These studies were clearly not designed to answer the question of occupational risk in the entire group of sex workers. Nevertheless, they were highly abundant among the studies excluded based on criterion 5 (eg, $71.3 \%$ of the excluded intervention studies were on HIV). On the other hand, an important proportion of studies excluded based on criterion 5 were designed specifically to answer the question of occupational risk but did not include a comparison to an adequate reference population. Second, evidence from the former Cochrane review by Curti et $^{\mathrm{a} \mathrm{l}^{3}}$ indicated that only a small number of occupational infectious diseases were reported to the designated registration systems, while Haagsma et al already stated that blood-borne pathogens were more frequently reported compared with zoonoses. ${ }^{2}$ As a result, the present body of literature might give an incomplete and to some extent unbalanced overview of occupational risks due to infectious diseases. In addition, it is difficult to compare national data due to differences in compensation criteria. The recent SARS-CoV-2 virus outbreaks draw attention to these types of occupational risk. For example, not only the healthcare workers but also uniformed service occupations (eg, police officers and firefighters) and other crucial sectors and essential services (cleaners, food industry and abattoir workers) were considered at-risk professions by Fedris during the lockdown period. ${ }^{7}$ Third, some occupational groups which involve travel abroad (eg, military personnel) might expose these workers to increased risk of infection (eg, hepatitis $\mathrm{E}$ virus) compared with the population of their country of origin, because of endemic infections in the country of destination. A decision needs to be made on the criteria which need to be fulfilled in order for such situations to be classified as an occupational infectious disease risk. For example, a consideration could be whether these workers have higher infectious disease risk than the local population (eg, because of lack of immunity or unadjusted behaviour). Fourth, a distinction could be made between occupation risk for endemic pathogens versus emerging (epidemic) infections. In the latter case, the occupational infection risk could be assessed through modelling approaches or by reference to historical outbreaks of emerging pathogens with similar biological and epidemiological characteristics.

\section{CONCLUSION}

Two main groups of biological agents of relevance for occupational health could be recognised. The first group comprised infectious diseases, including, but not limited to, zoonotic infections, for which certain occupational groups are at increased risk. The second group comprised organisms which, when present in the work environment, result in the production of bioaerosols. These bioaerosols can be either non-infectious (eg, endotoxins) or infectious (eg, influenza and measles virus). Within 
this domain, this review was restricted to infectious bioaerosols. Exposure to respiratory tract pathogens was mentioned in $81.1 \%$ of non-healthcare occupational groups that met our inclusion criteria. Many of these respiratory tract pathogens are readily transmitted where employees congregate, for example, in transportation vehicles, correctional facilities, military barracks, slaughterhouses and meat-packing plants, and shipyards (workplace risk factors). Currently, more research is needed on the impact of these workplace risk factors (eg, crowding, exposure to dust and welding fumes) and also on worker risk factors (eg, age and immunosuppression) to obtain a more systematic approach to preventing biological risks among non-healthcare employees. This combined risk factors approach (disease, workplace and worker risk factors) may result in an extended risk assessment strategy. By analysing existing knowledge of these risk factors, identifying new risks and susceptible risk groups, this review aimed to raise awareness of the issue and provide reliable information that can support efforts to establish effective preventive measures.

Acknowledgements The authors wish to thank Maarten F M Engel and Sabrina Meertens-Gunput from the Erasmus MC Medical Library for developing and updating the search strategies, and Professor Koen De Schrijver, Infectious Diseases expert from the Department of Family Medicine and Population Health, University of Antwerp, Belgium for his advice. This work was supported by Mensura Occupational Health Services (not-for-profit sector), as employer of SA.

Contributors ADS conceived of the original idea and participated as occupational infectious diseases expert. SA was the principal investigator and was the main contributor to most phases of the study: study initiation, protocol development, article screening and quality assessment, data synthesis, table creation, and the writing of the manuscript. SC developed the search strategy and performed the article screening for the scoping review, and assisted in the writing of the introduction and discussion part of the manuscript. For the updated systematic review, WMB developed the extensive search strategy and performed the systematic literature search, in collaboration with JAH. M-NS discussed the data synthesis and was involved as an occupational health expert. JAH assisted in article screening (the first 10\% of the systematic review), and editing of the manuscript. All authors discussed the results and contributed to the final manuscript.

Funding The authors have not declared a specific grant for this research from any funding agency in the public, commercial or not-for-profit sectors.

\section{Competing interests None declared.}

Patient consent for publication Not required.

Provenance and peer review Not commissioned; externally peer reviewed.

Supplemental material This content has been supplied by the author(s). It has not been vetted by BMJ Publishing Group Limited (BMJ) and may not have been peer-reviewed. Any opinions or recommendations discussed are solely those of the author(s) and are not endorsed by BMJ. BMJ disclaims all liability and responsibility arising from any reliance placed on the content. Where the content includes any translated material, BMJ does not warrant the accuracy and reliability of the translations (including but not limited to local regulations, clinical guidelines, terminology, drug names and drug dosages), and is not responsible for any error and/or omissions arising from translation and adaptation or otherwise.

Open access This is an open access article distributed in accordance with the Creative Commons Attribution 4.0 Unported (CC BY 4.0) license, which permits others to copy, redistribute, remix, transform and build upon this work for any purpose, provided the original work is properly cited, a link to the licence is given, and indication of whether changes were made. See: https://creativecommons.org/ licenses/by/4.0/.

\section{ORCID iD}

Sofie Acke http://orcid.org/0000-0002-9986-4866

\section{REFERENCES}

1 Hämäläinen P, Takala J, Boon Kiat T. Global estimates of occupational accidents and work-related illnesses 2017. workplace safety and health Institute, Singapore and Ministry of social Affairs and health, Finland. Available: http://www.icohweb.org/ site/images/news/pdf/Report\%20Global\%20Estimates\%20of\%200ccupational\% 20Accidents\%20and\%20Work-related\%20Illnesses\%202017\%20rev1.pdf [Accessed 15 Jun 2020].
2 Haagsma JA, Tariq L, Heederik DJ, et al. Infectious disease risks associated with occupational exposure: a systematic review of the literature. Occup Environ Med 2012;69:140-6.

3 Curti S, Sauni R, Spreeuwers D, et al. Interventions to increase the reporting of occupational diseases by physicians: a Cochrane systematic review. Occup Environ Med 2016:73:353-4.

4 Su C-P, de Perio MA, Cummings KJ, et al. Case investigations of infectious diseases occurring in workplaces, United States, 2006-2015. Emerg Infect Dis 2019;25:397-405.

5 Torén K, Blanc PD, Naidoo RN, et al. Occupational exposure to dust and to fumes, work as a welder and invasive pneumococcal disease risk. Occup Environ Med 2020;77:57-63.

6 Coggon D, Palmer KT. Are welders more at risk of respiratory infections? Thorax 2016;71:581-2.

7 Fedris. Federal agency for occupational risks. Available: https://www.fedris.be/sites/ default/files/assets/bcbz-2020-10-14_covid-19_nl_update_13102020.pdf [Accessed 20 Oct 2020].

8 Li Q, Guan X, Wu P, et al. Early transmission dynamics in Wuhan, China, of novel coronavirus-infected pneumonia. N Engl J Med 2020;382:1199-207.

9 Koh D. Occupational risks for COVID-19 infection. Occup Med 2020;70:3-5.

10 EFFAT. European Federation of trade unions, in the food, agriculture and tourism. Available: https://effat.org/wp-content/uploads/2020/06/EFFAT-Report-Covid19-outbreaks-in-slaughterhouses-and-meat-packing-plants-State-of-affairs-andproposals-for-policy-action-at-EU-level-30.06.2020.pdf [Accessed 12 Aug 2020].

11 Vonesch N, Binazzi A, Bonafede M, et al. Emerging zoonotic viral infections of occupational health importance. Pathog Dis 2019;77:ftz018.

12 Meima M, Kuijpers E, van den Berg C. Biological agents and prevention of workrelated diseases: a review. European risk Observatory report European agency for safety and health at work, 2020. Available: https://osha.europa.eu/en/publications/ review-specific-work-related-diseases-due-biological-agents/view [Accessed 5 Aug 2020].

13 Scottish Intercollegiate Guidelines Network (SIGN). Checklists and notes. Edinburgh: sign; 12/09/2012. version 2.0. produced by: Carolyn Sleith. Available: http://www. sign.ac.uk and http://www.sign.ac.uk/checklists-and-notes.html [Accessed 20 Jan 2020].

14 von Elm E, Altman DG, Egger M, et al. The strengthening the reporting of observational studies in epidemiology (STROBE) statement: guidelines for reporting observational studies. Epidemiology 2007;18:800-4.

15 Stone SP, Cooper BS, Kibbler CC, et al. The ORION statement: guidelines for transparent reporting of outbreak reports and intervention studies of nosocomial infection. Lancet Infect Dis 2007;7:282-8.

16 Gagnier JJ, Kienle G, Altman DG, et al. The care guidelines: consensus-based clinical case report Guideline development. J Clin Epidemiol 2014;67:46-51.

17 Eurofound. Sixth European working conditions survey - overview report (2017 update), publications office of the European Union, Luxembourg, 2017. Available: https://www.eurofound.europa.eu/publications/report/2016/working-conditions/ sixth-european-working-conditions-survey-overview-report [Accessed 5 Aug 2020].

18 Clark A, Jit M, Warren-Gash C, et al. Global, regional, and national estimates of the population at increased risk of severe COVID-19 due to underlying health conditions in 2020: a modelling study. Lancet Glob Health 2020;8:e1003-17.

19 Cassir N, Pascal L, Ferrieux D, et al. Outbreak of pneumococcal pneumonia among shipyard workers in Marseille, France, January to February 2020. Euro Surveill 2020;25:2000162.

20 Blanc PD, Annesi-Maesano I, Balmes JR, et al. The occupational burden of nonmalignant respiratory diseases. An official American thoracic Society and European respiratory Society statement. Am J Respir Crit Care Med 2019;199:1312-34.

21 Coman A, Maftei DN, Krueger WS, et al. Serological evidence for avian H9N2 influenza virus infections among Romanian agriculture workers. J Infect Public Health 2013;6:438-47.

22 Quan C, Wang Q, Zhang J, et al. Avian influenza A viruses among occupationally exposed populations, China, 2014-2016. Emerg Infect Dis 2019;25:2215-25.

23 Wang $X$, Fang S, Lu X, et al. Seroprevalence to avian influenza A(H7N9) virus among poultry workers and the general population in southern China: a longitudinal study. Clin Infect Dis 2014;59:e76-83.

24 Chaudhry M, Webby R, Swayne D, et al. Avian influenza at animal-human interface: one-health challenge in live poultry retail stalls of Chakwal, Pakistan. Influenza Other Respir Viruses 2020;14:257-65.

25 Huang SY, Yang JR, Lin YJ, et al. Serological comparison of antibodies to avian influenza viruses, subtypes H5N2, H6N1, H7N3 and H7N9 between poultry workers and non-poultry workers in Taiwan in 2012. Epidemiol Infect 2015;143:2965-74.

26 Wu J-Y, Lau EH, Yuan J, et al. Transmission risk of avian influenza virus along poultry supply chains in Guangdong, China. J Infect 2019;79:43-8.

27 Li S, Zhou Y, Song W, et al. Avian influenza virus H9N2 seroprevalence and risk factors for infection in occupational poultry-exposed workers in Tai'an of China. J Med Virol 2016:88:1453-6.

28 Pawar SD, Tandale BV, Raut CG, et al. Avian influenza H9N2 seroprevalence among poultry workers in Pune, India, 2010. PLoS One 2012;7:e36374. 
29 Esmaeili S, Bagheri Amiri F, Mokhayeri H, et al. Seroepidemiological study of Q fever, brucellosis and tularemia in butchers and slaughterhouses workers in Lorestan, Western of Iran. Comp Immunol Microbiol Infect Dis 2019;66:e101322.

30 De Lange MMA, Schimmer B, Vellema P, et al. Coxiella burnetii seroprevalence and risk factors in sheep farmers and farm residents in the Netherlands. Epidemiol Infect 2014;142:1231-44.

31 Mostafavi E, Molaeipoor L, Esmaeili S, et al. Seroprevalence of Q fever among highrisk occupations in the llam Province, the West of Iran. PLoS One 2019:14:e0211781.

32 Schimmer B, Lenferink A, Schneeberger $P$, et al. Seroprevalence and risk factors for Coxiella burnetii ( $Q$ fever) seropositivity in dairy goat farmers' households in the Netherlands, 2009-2010. PLoS One 2012;7:e42364.

33 Sun W-W, Cong W, Li M-H, et al. Coxiella burnetii seroprevalence and risk factors in cattle farmers and farm residents in three northeastern provinces and inner Mongolia autonomous region, China. Biomed Res Int 2016;2016:1-7.

34 Wilson LE, Couper S, Prempeh $\mathrm{H}$, et al. Investigation of a Q fever outbreak in a Scottish co-located slaughterhouse and cutting plant. Zoonoses Public Health 2010;57:493-8.

35 Alonso E, Lopez-Etxaniz I, Hurtado A, et al. Q fever outbreak among workers at a Waste-Sorting plant. PLoS One 2015;10:e0138817.

36 Nielsen SY, Mølbak K, Nybo Andersen AM, et al. Prevalence of Coxiella burnetii in women exposed to livestock animals, Denmark, 1996 to 2002. Euro Surveill 2013;18:e20528.

37 Bansal M, Kaur S, Deka D, et al. Seroepidemiology and molecular characterization of hepatitis E virus infection in swine and occupationally exposed workers in Punjab, India. Zoonoses Public Health 2017;64:662-72.

38 Chaussade H, Rigaud E, Allix A, et al. Hepatitis E virus seroprevalence and risk factors for individuals in working contact with animals. J Clin Virol 2013;58:504-8.

39 Krumbholz A, Mohn U, Lange J, et al. Prevalence of hepatitis E virus-specific antibodies in humans with occupational exposure to pigs. Med Microbiol Immunol 2012:201:239-44.
40 Kang $\mathrm{Y}-\mathrm{H}$, Cong W, Zhang $\mathrm{X}-\mathrm{Y}$, et al. Hepatitis E virus seroprevalence among farmers, veterinarians and control subjects in Jilin Province, Shandong Province and inner Mongolia autonomous region, China. J Med Virol 2017;89:872-7.

41 Teixeira J, Mesquita JR, Pereira SS, et al. Prevalence of hepatitis E virus antibodies in workers occupationally exposed to swine in Portugal. Med Microbiol Immunol 2017;206:77-81.

42 Carpentier A, Chaussade H, Rigaud E, et al. High hepatitis E virus seroprevalence in forestry workers and in wild boars in France. J Clin Microbiol 2012;50:2888-93.

43 Cui W, Sun Y, Xu A, et al. Hepatitis E seroprevalence and related risk factors among seafood processing workers: a cross-sectional survey in Shandong Province, China. Int $J$ Infect Dis 2016:49:62-6.

44 Khounvisith V, Tritz S, Khenkha L, et al. High circulation of hepatitis E virus in pigs and professionals exposed to pigs in Laos. Zoonoses Public Health 2018;65:1020-6.

45 Lagler H, Poeppl W, Winkler H, et al. Hepatitis E virus seroprevalence in Austrian adults: a nationwide cross-sectional study among civilians and military professionals. PLoS One 2014;9:e87669.

46 Lee J-T, Shao P-L, Chang L-Y, et al. Seroprevalence of hepatitis E virus infection among swine farmers and the general population in rural Taiwan. PLoS One 2013:8:e67180.

47 Liang H, Su S, Deng S, et al. The prevalence of hepatitis E virus infections among swine, swine farmers and the general population in Guangdong Province, China. PLoS One 2014;9:e88106.

48 Martins RMB, Freitas NR, Kozlowski A, et al. Seroprevalence of hepatitis E antibodies in a population of recyclable waste pickers in Brazil. J Clin Virol 2014;59:188-91.

49 Hinjoy S, Nelson KE, Gibbons RV, et al. A cross-sectional study of hepatitis E virus infection in healthy people directly exposed and unexposed to pigs in a rural community in northern Thailand. Zoonoses Public Health 2013;60:555-62.

50 Mughini-Gras L, Angeloni G, Salata C, et al. Hepatitis E virus infection in North Italy: high seroprevalence in swine herds and increased risk for swine workers. Epidemiol Infect 2017:145:3375-84. 